\title{
第40回内科学の展望 臓器移植の現状と将来展望
}

\section{9. まとめ \\ 池田 修一}

わが国の臓器移植は諸外国に比して大幅に遅 れていると言われている。，一番の理由は本邦で は十数年前まで脳死の概念が国民に受け入れら れなかったからであり，その契機となったのは 1968 年に札幌医科大学で行われた心蔵移植に際 しての脳死判定が非常に曖昧であったからであ る.この手術の執刀医である和田寿郎教授は後 に刑事告発を受けている. 以後わが国では約 30 年間脳死が国民的合意を得ることなく時が流れ たが, 最近になり“脳死がヒトの死である”こ とがやっと定着して, 本邦における臓器移植の 社会的環境が整ってきたようである．そこで今 回の内科学の展望では第 110 回日本内科学会総 会・講演会会頭の細谷龍男先生とも十分相談さ せて頂き,「臓器移植の現状と将来展望」という タイトルの基に, 本邦の第一人者の皆様から御 講演を賜りました。

会の冒頭に細谷会頭から臓器移植は年ごとに 内科医の日常診療と関連が深まっている主旨の 御挨拶をいただきました。 また, 今回の講演会 の盛り上がりを, 本年 4 月 12 日〜 14 日に東京で 開催される日本内科学会総会・講演会でのテー マ「多様性に対応する内科学」へ繋げていきた いとの会頭の意気込みが示されました.

引き続いて芦㺫淳太郎様からわが国における 脳死下からの臓器提供を行うための法整備と蔵
器移植ネットワークの役割についてお話があり ました。具体的には 1997 年 10 月に臓器移植法 が制定されて, 1999 年 2 月に本邦で初めての脳 死下臓器提供事例が出現したこと.さらに 2010 年 7 月には改正蔵器移植法が施行されて, 本人 の意思が不明であっても家族の承諾により脳死 下蔵器提供が可能となったこと, 小児心臓移植 への道が開けたことなどが説明されました，次 いで法的脳死判定の手順とその要点について森 田洋先生が概説しました。 その後, 肺, 心蔵, 肝蔵, 腎臓, 造血幹細胞移植の順番で個々の先 生から各論的お話がありました。肺移植の実施 件数は改正臓器移植法施行後急激に増加してお り，肺リンパ管症と間質性肺疾患が主な対象と なっているとのことでした，また移植を必要と する重症心疾患患者は多額の費用を用意して, 海外渡航を長年余儀なくされておりましたが, このことが国際的批判を受けたことを日本国民 が真摰に受け止めるべきであるとのお話があり ました. 肝移植に関しては現時点では生体ドナー からの移植件数が圧倒的に多いが, 将来的には 脳死ドナーからの移植が望ましいこと,さらに 肝臓に原因がある遺伝性全身疾患が肝移植で治 癒しうることも付け加えられました．腎移植で は心停止後摘出した臓器の生着率が非常に低い こと, 造血幹細胞移植の領域では過去 10 年間に

信州大学脳神経内科, リウマチ・膠原病内科

The 40th Scientific Meeting : Perspectives of Internal Medicine; Present situation and future extension of organ transplantation in Japan ; 9. Summary.

Shu-ichi Ikeda : Department of Medicine (Neurology and Rheumatology), Shinshu University School of Medicine, Japan. 
同種移植が 2 倍, 末梢血幹細胞移植が 1.5 倍に増 えており, 特に近年, 臍帯血移植の重要性が急 激に高まっているとのお話がありました.

最後に特別講演として前衆議院議長の河野洋 平様から自らの生体肝移植の経験談をお聞かせ いただきました．政治家という多忙を極める日 常生活の中で, ゆっくりと医師の診察を受ける 機会がなかったこと, 外務大臣当時に米国の病 院で末期の肝不全であることを告げられ，最後 は執務中に意識障害に陷り入院に至ったこと. そして意識が回復した病室にて長男の河野太郎 氏から生体肝移植ドナーの申し出があったが,
その後手術に至るまでの間に, 家族内で種々な 葛藤があったことなどをお話くださいました． 生体肝移植に遭遇した御家族の悩みが浮き彫り にされており, 非常に感銘を受ける内容でした. いずれの講演も要所を押さえた素晴らしい内容 であり, 扯聴された先生方には十二分に御満足 いただけたものと推察いたします。また御講演 いただきました先生方には遠路長野市まで足を お運びいただき，心から感謝いたしております。 最後になりましたが, 本学術会を契機としてわ が国の蔵器移植が一層発展することを願って稿 を終わりとします. 